\title{
Diet selection by Nguni goats in the Zululand Thornveld
}

\author{
N.A.D. Basha ${ }^{1}$, P.F. Scogings ${ }^{2}$ and I.V. Nsahlai ${ }^{1 \#}$ \\ ${ }^{1}$ Discipline of Animal and Poultry Science, School of Agricultural Sciences and Agribusiness, University of KwaZulu- \\ Natal, P/Bag X01, Scottsville, Pietermaritzburg 3209, South Africa \\ ${ }^{2}$ Department of Agriculture, University of Zululand, P/Bag X1001, KwaDlangezwa 3886, South Africa
}

\begin{abstract}
The aim was to determine diet selection of goats grazing/browsing in Zululand Thornveld. An experiment was done in spring (November 2007) and autumn (March/April 2008) at Owen Sitole College of Agriculture, KwaZulu-Natal. Diet selection was estimated using direct observation of animals and an indirect plant-based method. The browse species observed in the plant-based methods were: Gymnosporia senegalensis (Gs), Acacia nilotica (An), Acacia karroo (Ak), Scutia myrtina (Sm) and Dichrostachys cinerea (Dc). Selection was determined by observing at regular intervals 40 marked branches on 10 plants of each browse species. Direct observation of diet selection was done by observing two goats in a base herd of 24 castrated males when they were allowed to forage together in a paddock of 1 ha. Observations were made every minute for three hours in the morning and 1.5 hours in the afternoon. The relative abundance of the browse species in the veld was determined and used to estimate the selection index (utilization relative to availability). In both seasons, the three most selected species according to the plant-based observations were Sm, Ak and Dc. Consistently, An experienced moderate defoliation and Gs the least. However, on the basis of the selection index the species followed the order: An $>$ Dc $>A k>S m>G s$ in spring and $A n>S m>D c>A k>G s$ in autumn. The selection index was negatively correlated to all fibre attributes although the correlation attained significance only for NDF, ADF and lignin but not for tannins and cellulose. Both methods did not rank species in the same order, thus suggesting the need for further methodological refinement.
\end{abstract}

Keywords: Browse, forage, herbivore, savannah

\#Corresponding author. E-mail: nsahlaii@ukzn.ac.za

\section{Introduction}

In Africa, natural vegetation makes up a major part of the diet of ruminant livestock. Thus, in order to enhance livestock production, it is imperative to improve pastures, comprising of grass and browse species. The improvement of such pastures is impossible to achieve without adequate understanding of browsebrowser interaction and feeding behaviour. Bergström (1992) suggested active interaction between browsers and woody plants, in that woody plants respond to browsing and impact on feeding behaviour. Browsers have been shown to choose plants with high growth rates over plants with slow growth rates (Danell et al., 1985). Animals have been shown to be able to distinguish between plant types and their parts (Hodgson 1986). Biochemical and nutritive characteristics of feed provide the option to select the diet which satisfies the goats' requirements (Fedele et al., 2002). Digestibility is influenced by plant fibre (Jung \& Allen, 1995) whilst tannin may control diet selection and food intake since it creates unacceptable taste or reduces nutrient (protein) availability in the gastrointestinal tract (Arnold et al. 1980; Robbins et al., 1987). In a study by Montossi et al. (1997) in New Zealand, a low content of condensed tannin $(<0.2 \%)$ did not influence lamb performance. Goats' feeding behaviour depends on the associative effects of diet items rather than their specific nutritive value, since goats maximize and balance intake without incurring digestive disorders (Fedele et al., 2002). The aim of this study was to determine the diet selection of goats grazing/browsing in Zululand Thornveld.

\section{Materials and Methods}

Two experiments were conducted using two paddocks (1 ha each) during the spring (November 2007) and autumn (March/April 2008) seasons at the Owen Sitole College of Agriculture (OSCA), Empangeni, South Africa. OSCA is located at $28^{\circ} 57^{\prime} 45^{\prime \prime}-28^{\circ} 57^{\prime} 22^{\prime \prime}$ latitude and $31^{\circ} 55^{\prime} 31^{\prime \prime}-31^{\circ} 57^{\prime} 22^{\prime \prime} E$ longitude within the Coastal Forest and Thornveld (Van der Linden et al., 2005). The mean annual rainfall of OSCA is 
$1022 \mathrm{~mm}$, with a third of it falling in mid to late summer (Van der Linden et al., 2005). The study area was located north of the main gate of OSCA. The paddocks were fenced and a pen (9 $\mathrm{m} \times 6 \mathrm{~m})$ was erected in one corner of the paddock for holding animals at night, which was equipped with one water trough.

Twenty-four castrated male Nguni goats were used. The study focused on five dominant browse species: Gymnosporia senegalensis, Acacia nilotica, Acacia karroo, Scutia myrtina and Dichrostachys cinera. The browse species were randomly sampled by collecting leaves $1.0-1.5 \mathrm{~m}$ above ground from three trees per species. Samples were kept in paper bags and air-dried prior to oven-drying at $60{ }^{\circ} \mathrm{C}$ for 48 hours. The leaves were ground through a 1-mm mesh sieve and stored in plastic bottles.

For estimating relative abundance of woody species, the belt transect method was used. Transects of $2 \mathrm{~m}$ width, oriented north-south, were systematically placed $20 \mathrm{~m}$ apart. Each transect started and ended 10 $\mathrm{m}$ from the sides of the paddock. Transects were surveyed in 20-m lengths. About $5 \%$ of the paddock area was sampled. In sampled transects, woody plants were identified, the height of all woody plants was measured and the proportion with browseable material below $1.5 \mathrm{~m}$ height estimated. The relative abundance of each species was calculated as the number of plants of a species divided by the total number of plants of all species x 100. The density of each species (plants $/ \mathrm{m}^{2}$ ) was calculated as the number of plants of a species divided by the area of paddock.

An indirect plant-based method of diet selection involved marking 40 branches (on 10 plants) per species. Every two days, all branches were inspected and scored as browsed or not browsed. The cumulative proportion of marked branches was calculated and plotted against days. An animal-based method (direct method) was also used to determine diet selection. During foraging, two goats were selected randomly from the herd during each day of recording (different goats for each day) and closely observed continuously by two people. The selected browse species under study were recorded every minute. Browsing activity on species not being studied, and grazing activity, was recorded as 'other browse' and 'grazing', respectively. Observations were made for $3 \mathrm{~h}$ in the morning and $1.5 \mathrm{~h}$ in the afternoon on alternate days for a total of six days. Selection index (SI; utilization relative to availability) was estimated as: $\mathrm{SI}_{\mathrm{y}}=\left(\mathrm{C}_{\mathrm{y}} / \mathrm{D}\right) / \mathrm{RA}_{\mathrm{y}}$, where $\mathrm{SI}_{\mathrm{y}}$ is the selection index for species ' $y$ ', $C_{y}$ is the number of times species ' $y$ ' was consumed, $D$ is the sum of all observations of all species in the diet, and $\mathrm{RA}_{\mathrm{y}}$ is the relative abundance of species ' $\mathrm{y}$ '.

Crude protein was determined using the AOAC $\left(16^{\text {th }}\right.$ edition) method 990.03 (LECO. FP2000, Nitrogen analyzer). Neutral detergent fibre (NDF), acid detergent fibre (ADF) and acid detergent lignin (ADL) were determined using the methods of Van Soest et al. (1991) applied to ANKOM Technology Technique. Condensed tannin (CT) was determined according to the method described by Makkar (1995).

The diet proportion, diet selection index and relative abundance were analyzed using the GLM procedure of SAS programme (2000). Correlations between selection index and chemical properties were determined.

\section{Results \& Discussion}

In both seasons, the three most selected species according to the plant-based observations were $S$. myrtina, A. karroo and D. cinerea. Consistently, A. nilotica experienced moderate defoliation and $G$. senegalensis the least (Figure 1). Dziba et al. (2003) in the Eastern Cape obtained the same order of preference for S. myrtina and A. karroo. Yayneshet (2008) showed that goats preferred D. cinerea. Sanon (2007) mentioned that the lowest intake was of $G$. senegalensis.

However, on the basis of the selection index the species followed the order: A. nilotica, D. cinerea, $A$. karroo, S. myrtina, G. senegalensis in spring and A. nilotica, S. myrtina, D. cinerea, A. karroo, G. senegalensis in autumn (Table1). A. karroo and D. cinerea had similar indices in spring and autumn (1.18 and $1.4 ; 1.19$ and 1.36 , respectively) perhaps because both plants had green leaves in both seasons. A. nilotica and $S$. myrtina registered different indices in both season, but differences were much wider in spring than in autumn. This suggests that preference ranking might be affected by season (Dziba et al., 2003). Milne et al. (1979) found that the intake rate of grazing sheep differed between summer and autumn. Goats might avoid a season's twigs as a result of their high tannin contents and their location within the plant canopy (Provenza \& Malechek, 1984).

The chemical composition is shown in Table 2. The selection index was negatively correlated to all fibre attributes although the correlation attained significance $(\mathrm{P}<0.05)$ only for NDF, ADF and lignin (Table 2). Selection of diet items may sometimes be a function of quality and other times a function of quantity 
(Shipley et al., 1999). Arnold (1981) suggested that herbivores select diets based on the concentration of nutrients relative to toxins rather than on availability.
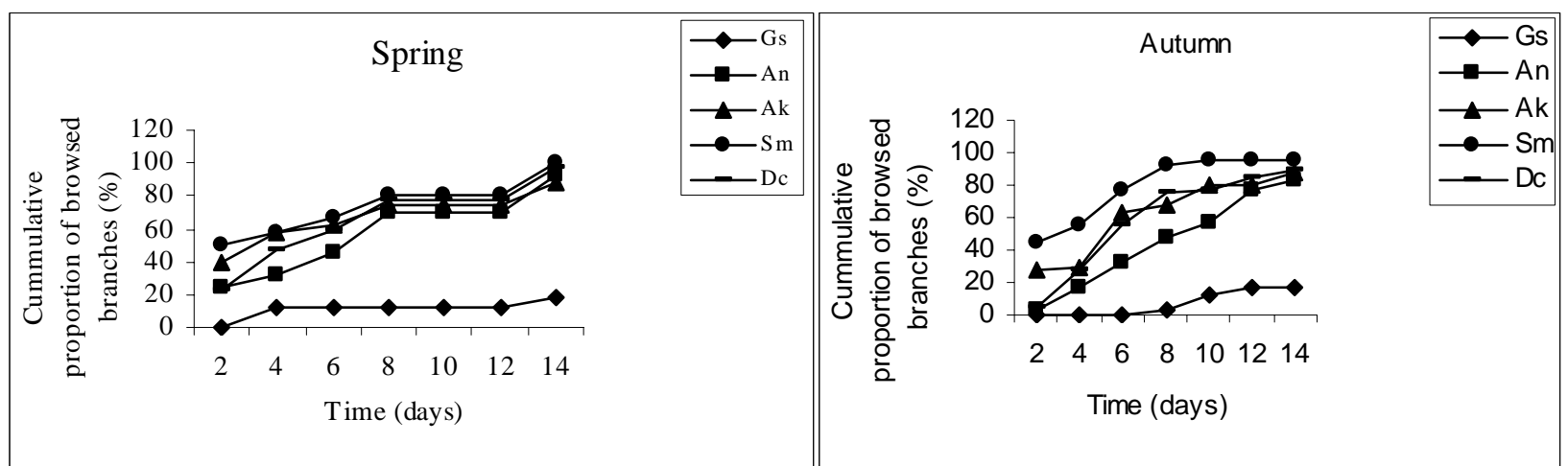

Figure 1 Defoliation rate of branches of browse species in spring and autumn (Gs $=G$. senegalensis, $A n=A$. nilotica, $\mathrm{Ak}=$ A. karroo, $\mathrm{Sm}=$ S. myrtina and $\mathrm{Dc}=$ D. cinera $)$.

Table 1 Density of forage trees, browseable trees within species (BAS), relative abundance of browseable species (RAS), relative abundance of a browseable species in the diet (Diet), and diet selection index (Sindex)

\begin{tabular}{lccccccccccc}
\hline & \multicolumn{1}{l}{$\begin{array}{l}\text { Density } \\
\text { (plants/ha) }\end{array}$} & \multicolumn{3}{c}{ BAS (plants/ha) } & \multicolumn{2}{c}{ RAS } & \multicolumn{2}{c}{ Diet } & \multicolumn{2}{c}{ S index } \\
\hline & S & A & S & A & S & A & S & A & S & A \\
\hline & & & & & & & & & & & \\
G. senegalensis & 949 & 1280 & 939 & 1248 & 0.077 & 0.090 & 0.005 & 0.014 & 0.10 & 0.27 \\
A. nilotica & 653 & 500 & 520 & 360 & 0.042 & 0.026 & 0.116 & 0.102 & 4.08 & 6.35 \\
A. karroo & 2439 & 1860 & 2224 & 1840 & 0.181 & 0.133 & 0.136 & 0.099 & 1.18 & 1.19 \\
S. myrtina & 1071 & 860 & 908 & 820 & 0.074 & 0.059 & 0.034 & 0.125 & 0.68 & 3.25 \\
D. cinerea & 898 & 1460 & 867 & 1361 & 0.071 & 0.099 & 0.065 & 0.083 & 1.40 & 1.36 \\
Other browses & 6936 & 8740 & 6804 & 8172 & 0.555 & 0.592 & 0.306 & 0.201 & 0.82 & 0.55 \\
Grazing & & & & & & & 0.338 & 0.374 & - & - \\
RMSE & & & & & & & 0.0607 & 0.027 & 0.55 & 1.13 \\
P< & & & & & & & 0.05 & 0.05 & 0.05 & 0.05 \\
& & & & & & & & & & \\
\hline
\end{tabular}

$\mathrm{S}$ = spring, $\mathrm{A}=$ Autumn; OB - other browse species; RMSE is the root mean square error.

Table 2 Chemical composition of experimental species and correlation coefficients with diet selection index

\begin{tabular}{|c|c|c|c|c|c|c|}
\hline Species & $\mathrm{CP}(\mathrm{g} / \mathrm{kg})$ & NDF (g/kg) & ADF (g/kg) & ADL (g/kg) & CT (g/kg) & Cell (g/kg) \\
\hline G. senegalensis & 73.8 & 486.4 & 304.8 & 205.3 & 77.5 & 99.5 \\
\hline A. nilotica & 114.7 & 460.7 & 259.8 & 172.8 & 132.3 & 87.0 \\
\hline A. karroo & 123.4 & 272.9 & 139.3 & 78.3 & 20.3 & 61.0 \\
\hline S. myrtina & 125.7 & 431.4 & 288.0 & 213.2 & 100.0 & 74.8 \\
\hline D. cinerea & 123.2 & 523.6 & 316.9 & 198.1 & 57.9 & 118.8 \\
\hline \multicolumn{7}{|c|}{ Correlation with selection index } \\
\hline Spring & $0.56^{\mathrm{NS}}$ & $-0.88^{*}$ & $-0.88^{*}$ & $-0.90 *$ & $-0.76^{\mathrm{NS}}$ & $0.62^{\mathrm{NS}}$ \\
\hline Autumn & $0.48^{\mathrm{NS}}$ & $-0.87^{*}$ & $-0.96 *$ & $-0.97 *$ & $-0.46^{\mathrm{NS}}$ & $0.69^{\mathrm{NS}}$ \\
\hline
\end{tabular}

$\overline{\mathrm{CP}}$ - crude protein; NDF - neutral detergent fibre; ADF - acid detergent fibre; CT - condensed tannin; Cell - cellulose. NS $(\mathrm{P}>0.05) ; *(\mathrm{P}<0.05)$. 


\section{Conclusion}

Indirect plant-based and direct animal-based methods did not rank browse species in the same order, thus suggesting the need for further methodological refinement. Diet selection appears to be influenced by the fibre constituents.

\section{Aknowledgements}

This research was funded by the National Research Foundation. Francois du Toit assisted with logistical support. Casper Nyamukanza, Andries Malate, Sicelo Dludla and M. Mofokeng assisted with field work.

\section{References}

Arnold, G.W., 1981. Grazing behaviour. In: Grazing Animals. Ed. Morley, F.W., Elsevier Scientific, Press Amsterdam. pp. 79-104.

Arnold, G.W., deBoer, E.S. \& Boundy, C.A.P., 1980. The influence of odour and taste on the food preferences and food intake of sheep. Aust. J. Agric. Res. 31, 571-587.

Bergström, R., 1992. Browse characteristics and impact of browsing on trees and shrubs in Africa savannas. J. Vegetation Sci. 3, 315-324.

Danell, K., Huss-Danell, K. \& Bergström, R., 1985. Interactions between browsing moose and two species of birch in Sweden. Ecol. 66, 1867-1878.

Dziba, L.E., Scogings, P.F., Gordon, I.J. \& Raats, J.G., 2003. Effects of season and breed on browse species intake rates and diet selection by goats in the False Thornveld of the Eastern Cape, South Africa. Small Rumin. Res. 47, 17-30.

Fedele, V., Claps, S., Rubino, R., Calandrelli, M. \& Pilla, A.M., 2002. Effect of free-choice and traditional feeding systems on goats feeding behaviour and intake. Livest. Prod. Sci. 74, 19-31.

Hodgson, J., 1986. Grazing behaviour and herbage intake. In: Grazing. Ed. Frame, J., Br. Grassl. Soc. pp. 113-138.

Jung, H.G. \& Allen, M.S., 1995. Characteristics of plant cell walls affecting intake and digestibility of forages by ruminants. J. Anim. Sci. 73, 2774-2790.

Makkar, H.P.S., 1995. Quantification of tannins: A laboratory manual. International Centre for Agricultural Research in the Dry Areas. Aleppo, Syria.

Milne, J.A., Bagley, L. \& Grant, A.S., 1979. Effects of season and level of grazing on the utilization of heather by sheep. 2. Diet selection and intake. Grass For. Sci. 34, 45-53.

Montossi, F., Hodgson, J. \& Morris, S.T., 1997. Herbage intake, ingestive behaviour and diet selection, and effects of condensed tannins upon body and wool growth in lambs grazing Lolium perenne and Holcus lanatus swards in summer. N. Z. J. Agric. Res. 40, 449-461.

Provenza, F.D. \& Malechek, J.C., 1984. Diet selection by domestic goats in relation to blackbrush twig chemistry. J. Appl. Ecol. 21, 831-841.

Robbins, C.T., Hanley, T.A., Hagerman, A.E., Hjeljord, O., Baker, D.L., Schwartz, C.C. \& Mautz, W.W., 1987. Role of tannins in defending plants against ruminants: reduction in protein availability. Ecol. 68, 98-107.

Sanon, H.O., 2007. The importance of some Sahelian browse species as feed for goats. PhD dissertation, Swedish University of Agricultural Sciences Uppsala.

SAS, 2000. Statistical Analysis System user's guide (Version 8). SAS Institute Inc., SAS Campus Drive, Cary, N.C., USA.

Shipley, L.A., Illius, A.W., Danell, K., Hobbs, N.T. \& Spalinger, D.E., 1999. Predicting bite size selection of mammalian herbivores: a test of a general model of diet optimization. Oikos. 84, 55-68.

Van der Linden, J.P., Siebert, S.J., Siebert, F., Ferreira, D.P. \& Bredenkamp, G.J., 2005. Vegetation of the Owen Sitole College of Agriculture in Zululand, KwaZulu-Natal. Koedoe 48, 33-56. Pretoria. ISSN 0075-6458.

Van Soest, P.J., Robertson, J.B. \& Lewis, B., 1991. Methods for dietary fiber, neutral detergent fiber, and nonstarch polysaccharides in relation to animal nutrition. J. Dairy Sci. 74, 3583-3597.

Yayneshet, T., Eik, L.O. \& Moe, S.R., 2008. Influences of fallow age and season on the foraging behaviour and diet selection pattern of goats (Capra hircus L.). Small Rumin. Res. 77, 25-37. 